\title{
Analisis Persepsi Pengguna Jalan Terhadap Fasilitas Penyeberangan di Ruas Jalan AP.Pettarani
}

\author{
Oktavianty Batto*1, Rais Rachman ${ }^{\star 2}$, Monika D.M.Palinggi*3 \\ *1 Mahasiswa Program Studi Teknik Sipil, Universitas Kristen Indonesia Paulus, Makassar, Indonesia \\ oktabatto@gmail.com \\ ${ }^{* 2 * 3}$ Dosen Program Studi Teknik Sipil, Universitas Kristen Indonesia Paulus, Makassar, Indonesia \\ rais.rachman@gmail.com dan monikadatumirring@gmail.com
}

\begin{abstract}
ABSTRAK
Jembatan Penyeberangan Orang merupakan salah satu fasilitas pejalan kaki yang sangat bermanfaat bagi kelancaran lalu lintas. Sedangkan dari hasil pengamatan, Jembatan Penyeberangan Orang di Jalan A.P. Pettarani belum dimanfaatkan secara optimal, sebagai contoh pejalan kaki masih mengunakan badan jalan sebagai media untuk penyeberangan. Penelitian ini bertujuan untuk mengetahui karakterisistik pejalan kaki dan persepsi pejalan kaki terhadap fasilitas Jembatan Penyeberangan Orang di Jalan A.P.Pettarani. Metode yang digunakan adalah metode wawancara dengan menggunakan kuisioner atau angket dan dianalisis dengan metode analisis deskriptif. Berdasarkan hasil penelitian diperoleh karakterisitik pejalan kaki lebih didominasi oleh laki-laki dengan rentang umur yaitu 17-26 tahun oleh pelajar/mahasiswa, dan persepsi pejalan kaki sangat bervariasi baik yang menggunakan maupun yang tidak menggunakan Jembatan Penyeberangan Orang A.P Pettarani. Dari semua variabel yang diteliti, variabel yang paling mempengaruhi adalah variabel X3 yaitu jarak tempuh yang mana pada beberapa kasus pejalan kaki enggan untuk menggunakan Jembatan Penyeberangan Orang karena jarak dari titik melakukan perjalanan ke tempat tujuan menjadi lebih jauh. Sehingga terkadang banyak pejalan kaki yang lebih memilih untuk melintas di badan jalan.
\end{abstract}

Kata Kunci : pejalan kaki, karakteristik, persepsi, jembatan penyeberangan orang

\begin{abstract}
Pedestrian Bridge is a pedestrian facility that is very useful for smooth traffic. Meanwhile, from the observations, the Pedestrian Bridge on Jalan A.P. Pettarani has not been used optimally, for example, pedestrians still use the road as a medium for crossing. This study aims to determine the characteristics of pedestrians and the perceptions of pedestrians towards the Pedestrian Bridge facility on Jalan A.P. Pettarani. The method used is the interview method using a questionnaire or questionnaire and analyzed by descriptive analysis method. Based on the results of the study, it was found that the characteristics of pedestrians were more dominated by men with an age range of 17-26 years by students, and the perceptions of pedestrians varied greatly, both those who used and did not use the A.P Pettarani Pedestrian Bridge. Of all the variables studied, the variable that influenced the most was the variable $\mathrm{X} 3$, namely the distance traveled in which in some cases pedestrians were reluctant to use the Pedestrian Bridge because the distance from the point of traveling to the destination was further away. So that sometimes many pedestrians prefer to cross the road.
\end{abstract}

Keywords: pedestrian, characteristics, perception, pedestrian bridge

\section{PENDAHULUAN}

Jalan A.P. Pettarani merupakan salah satu jalan terpanjang di Makassar dengan panjang jalan 4300 $\mathrm{m}$ dan lebar $16 \mathrm{~m}$ yang hanya memiliki satu fasilitas Jembatan Penyeberangan Orang. Dengan kondisi jalan yang cukup padat dan adanya pembangunan jalan tol layang membuat lalu lintas semakin padat, ditambah lagi adanya pejalan kaki yang menyeberang tidak pada tempatnya. Pejalan kaki memiliki peran penting untuk mendapatkan lalu lintas yang aman, cepat, lancar, tertib dan teratur.

Kondisi daripada Jembatan Penyeberangan Orang yang pada beberapa kasus kurang terawat atau disalahgunakan, membuat pejalan kaki merasa tidak nyaman dan memilih untuk tidak menggunakan fasilitas Jembatan Penyeberangan Orang. Hal ini bisa dilihat pada kenyataannya bahwa jembatan penyeberangan sebagai salah satu fasilitas penyeberangan jarang dipakai dan terkadang sering disalahfungsikan untuk duduk-duduk, tempat mangkal gelandangan serta daerah yang rawan kejahatan.

Adapun pejalan kaki kurang menyadari untuk menggunakan fasilitas yang ada. Sedangkan Jembatan Penyeberangan Orang sendiri memberikan begitu banyak keuntungan kepada pejalan kaki, seperti keselamatan total karena tidak perlu melewati jalan raya, tidak perlu menunggu terlalu lama untuk menyeberang apabila jalanan 
padat kendaraan atau menunggu untuk menggunakan fasilitas pejalan kaki lainnya yang berada langsung di badan jalan. Keberadaan daripada Jembatan Penyeberangan Orang sendiri terkesan kurang dimanfaatkan dan membuat pejalan kaki melintas di badan jalan. Namun sering keberadaan penyeberang jalan tersebut pada tingkat tertentu akan mengakibatkan konflik yang tajam dengan arus kendaraan yang berakibat pada tundaan lalu lintas dan tingginya tingkat kecelakaan.

Tujuan dari penelitian ini ialah untuk mengetahui karakteristik pejalan kaki di Jalan A.P. Pettarani dan mengetahui persepsi pejalan kaki terhadap fasilitas Jembatan Penyeberangan Orang di Jalan A.P. Pettarani.

Ruang lingkup penelitian hanya dilakukan pada area dari Jembatan Penyeberangan Orang di depan Toko Ramayana di Jalan A.P. Pettarani. Pengambilan sampel dilakukan hanya di hari kerja yaitu antara hari senin sampai dengan hari jumat.

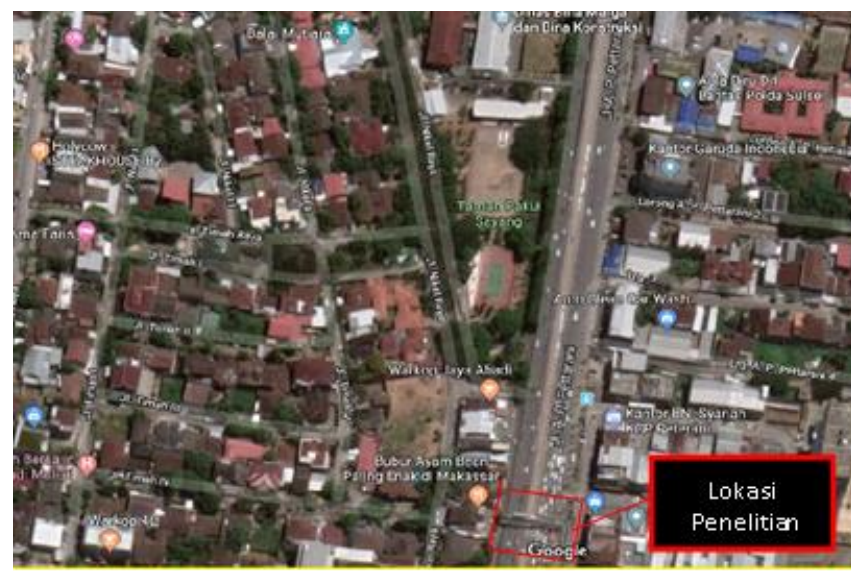

Gambar 1. Lokasi penelitian

Pengumpulan data responden dilakukan pada hari kerja, yaitu pada hari Selasa,17 Juni 2019; Rabu, 18 Juni 2019 dan Kamis, 19 Juni 2019 dan jam puncak yaitu pagi jam 08.00-10.00, siang 11.00-13.00 dan sore 16.00-18.00 WITA.

Beberapa penelitian sejenis yaitu Hasil dari penelitian ini adalah gambaran dari berbagai perilaku pejalan kaki dalam menggunakan fasilitas penyeberangan ditinjau dari aspek keamanan dan keselamatan, kenyamanan, dan Kemudahan akses sekaligus menggambarkan kondisi sarana penyeberangan yang tersedia, sehingga dapat menjadi dijadikan bahan masukan kebijakan pembangunan dan perancangan fasilitas penyeberangan yang lebih baik. [1], Aspek yang dianggap kurang di jalur pejalan kaki Jalan Pemuda Kota Magelang adalah kesesuaiannya untuk pengguna dengan kebutuhan khusus perlu dilakukan perbaikan terkait hal tersebut [2], tingkat pelayanan jembatan penyeberangan orang di Pasar induk Kramat Jati adalah A[3], Faktorfaktor yang perlu ditingkatkan dalam jalur pedestrian di Kota Surabaya JI.Pemuda yaitu kebersihan dan kelengkapan fasilitas kebersihan trotoar yang belum memadai, fasilitas penerangan yang belum merata, ketersediaan fasilitas bagi oang berkebutuhan khusus yang belum memadai, penyediaan pagar pembatas dengan jalan, serta aktivitas kendaraan yang berhenti / parkir di tepi jalur pedestrian[4], hubungan antara penyeberang dengan volume lalu lintas hanya $0.2 \%$ menandakan tergolong hubungan sangat rendah $\hat{A}$ Fasilitas penyeberangan pelican dengan pelindung direkomendasikan dengan menggunakan pulau pelindung dengan dilengkapi lampu isyarat mengingat jalan Kartini Bandar Lampung adalah jalan satu arah dengan empat lajur [5], pada JI.Pemuda, Kota Klaten dari hasil persepsi pejalan kaki terdapat empat indikator yang cenderung menunjukan penilaian buruk atau sangat buruk, yaitu peluang menyeberang, fasilitas penyeberangan, perilaku pengendara dan permukaan trotoar[6].

\section{METODE}

Variabel penelitian adalah segala sesuatu yang berbentuk apa saja yang ditetapkan oleh peneliti untuk dipelajari sehingga diperoleh informasi tentang hal tersebut. Variabel yang digunakan dalam penelitian ini adalah variabel bebas dan variabel terikat.

\section{Variabel Bebas (Independent Variable)}

Variabel bebas adalah variabel yang mempengaruhi, yang menyebabkan timbulnya atau berubahnya variabel terikat. Variabel bebas yang digunakan dalam penelitian ini adalah persepsi.

\section{Variabel Terikat (Dependent Variable)}

Variabel terikat adalah variabel yang dipengaruhi karena adanya variabel bebas. Variabel terikat yang digunakan dalam penelitian ini adalah kinerja. Definisi operasional penelitian ini dapat dilihat pada Tabel 1 berikut: 
Tabel 1. Variabel

\begin{tabular}{|c|c|c|c|}
\hline Variabel & Definisi & Indikator & Skala \\
\hline $\begin{array}{l}\text { Jenis } \\
\text { Kelamin }\end{array}$ & 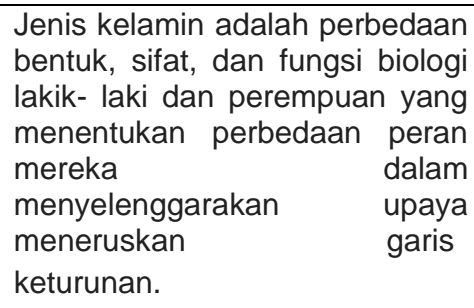 & $\begin{array}{l}\text { Perbedaan ini terjadi karena mereka } \\
\text { memiliki alat-alat untuk meneruskan } \\
\text { keturunan yang berbeda, yang } \\
\text { disebut alat reproduksi. }\end{array}$ & $\begin{array}{l}\text { Skala } \\
\text { Likert }\end{array}$ \\
\hline Umur & $\begin{array}{l}\text { Umur adalah rentang kehidupan } \\
\text { yang diukur dengan tahun, } \\
\text { dikatakan masa awal dewasa } \\
\text { adalah usia } 18 \text { tahun sampai } 40 \\
\text { tahun, dewasa madya adalah } 41 \\
\text { tahun sampai } 60 \text { tahun, dewasa } \\
\text { lanjut }>60 \\
\text { tahun. }\end{array}$ & $\begin{array}{l}\text { Umur adalah lamanya hidup dalam } \\
\text { tahun yang dihitung sejak dilahirkan } \\
\text { (Harlock, 2004). }\end{array}$ & $\begin{array}{l}\text { Skala } \\
\text { Likert }\end{array}$ \\
\hline $\begin{array}{l}\text { Jenis } \\
\text { Pekerjaan }\end{array}$ & $\begin{array}{l}\text { Pekerjaan adalah suatu kegiatan } \\
\text { atau aktivitas yang dilakukan } \\
\text { oleh manusia bertujuan untuk } \\
\text { memenuhi kebutuhan hidupnya. }\end{array}$ & $\begin{array}{l}\text { Pekerjaan itu sendiri adalah terbagi } \\
\text { menjadi dua macam yaitu pekerjaan } \\
\text { yang menghasilkan barang dan } \\
\text { pekerjaan yang menghasilkan barang } \\
\text { dan pekerjaan yang menghasilkan } \\
\text { jasa. }\end{array}$ & $\begin{array}{l}\text { Skala } \\
\text { Likert }\end{array}$ \\
\hline $\begin{array}{l}\text { Tujuan } \\
\text { Perjalanan } \\
\text { (X1) }\end{array}$ & $\begin{array}{l}\text { H. A. } \\
\text { berpendapat bahwa orang } \\
\text { melakukan perjalanan karena } \\
\text { alas an kebutuhan atau need. }\end{array}$ & 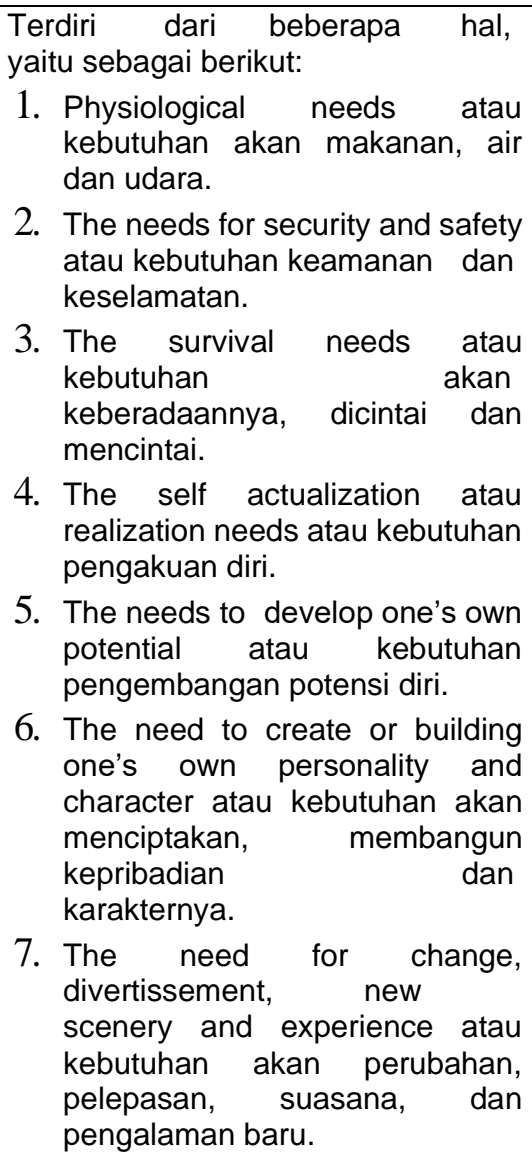 & $\begin{array}{l}\text { Skala } \\
\text { Likert }\end{array}$ \\
\hline
\end{tabular}




\begin{tabular}{|c|c|c|c|}
\hline $\begin{array}{l}\text { Frekuensi } \\
\text { menggunak } \\
\text { an fasilitas } \\
\text { JPO (X2) }\end{array}$ & $\begin{array}{l}\text { Banyaknya suatu fasilitas } \\
\text { khususnya JPO digunakan } \\
\text { dalam beberapa waktu. }\end{array}$ & $\begin{array}{l}\text { Biasanya didasarkan pada keinginan } \\
\text { atau persepsi dari diri orang yang } \\
\text { menggunakan. }\end{array}$ & $\begin{array}{l}\text { Skala } \\
\text { Likert }\end{array}$ \\
\hline $\begin{array}{l}\text { Jarak tempuh } \\
\text { (X3) }\end{array}$ & $\begin{array}{l}\text { Jarak adalah angka yang } \\
\text { menunjukkan seberapa jauh } \\
\text { suatu benda berubah posisi } \\
\text { melalui suatu lintasan tertentu. } \\
\text { Dalam } \\
\text { fisika atau dalam pengertian } \\
\text { sehari-hari. }\end{array}$ & $\begin{array}{l}\text { Jarak dapat } \\
\text { estimasi jarak fisik dari dua buah } \\
\text { posisi berdasarkan kriteria tertentu } \\
\text { (misalnya jarak tempuh antara } \\
\text { Jakarta-Bandung) }\end{array}$ & $\begin{array}{l}\text { Skala } \\
\text { Likert }\end{array}$ \\
\hline $\begin{array}{l}\text { Kondisi fasilitas } \\
\text { JPO (X4) }\end{array}$ & $\begin{array}{l}\text { Keadaaan } \text { daripada suatu } \\
\text { fasilitas baik } \\
\text { maupun kelebihan }\end{array}$ & $\begin{array}{l}\text { Biasanya kekurangan atau kelebihan } \\
\text { diakibatkan karena kondisi finansial } \\
\text { maupun perhatian terhadap fasilitas } \\
\text { tersebut. }\end{array}$ & $\begin{array}{l}\text { Skala } \\
\text { Likert }\end{array}$ \\
\hline $\begin{array}{l}\text { Kenyamanan } \\
\text { (X5) }\end{array}$ & $\begin{array}{l}\text { Kenyamanan adalah rasa yang } \\
\text { timbul jika seseorang merasa } \\
\text { diterima apa adanya, serta } \\
\text { senang dengan situasi dan } \\
\text { kondisi yang ada sehingga } \\
\text { seseorang akan } \\
\text { merasakan kenyamanan. }\end{array}$ & $\begin{array}{l}\text { Diakibatkan juga oleh faktor yang } \\
\text { berada di sekelilingnya dan } \\
\text { merupakan kebiasaan yang terjadi } \\
\text { berulang-ulang. }\end{array}$ & $\begin{array}{l}\text { Skala } \\
\text { Likert }\end{array}$ \\
\hline $\begin{array}{l}\text { Alasan tidak } \\
\text { menggunakan } \\
\text { fasilitas }(\mathrm{X} 6)\end{array}$ & $\begin{array}{l}\text { Merupakan suatu perasaan yang } \\
\text { timbul terhadap suatu kejadian } \\
\text { atau peristiwa dalam hal ini tidak } \\
\text { menggunakan JPN }\end{array}$ & $\begin{array}{l}\text { Biasanya dipengaruhi oleh kondisi } \\
\text { dan keadaan sekitar seperti waktu, } \\
\text { jarak, kenyamanan dan faktor lainnya }\end{array}$ & $\begin{array}{l}\text { Skala } \\
\text { Likert }\end{array}$ \\
\hline $\begin{array}{l}\text { Alasan } \\
\text { menggunkan } \\
\text { fasilitas (X7) }\end{array}$ & $\begin{array}{l}\text { Merupakan suatu perasaan yang } \\
\text { timbul terhadap suatu kejadian } \\
\text { atau peristiwa dalam hal } \\
\text { ini menggunakan JPO. }\end{array}$ & $\begin{array}{l}\text { Biasanya dipengaruhi oleh kondisi } \\
\text { dan keadaan sekitar seperti waktu, } \\
\text { jarak, kenyamanan dan faktor } \\
\text { lainnya. }\end{array}$ & $\begin{array}{l}\text { Skala } \\
\text { Likert }\end{array}$ \\
\hline $\begin{array}{l}\text { Kekurangan } \\
\text { fasilitas (X8) }\end{array}$ & $\begin{array}{l}\text { Kekurangan dapat } \\
\text { menyatakan nama dari } \\
\text { seseorang, tempat, atau semua } \\
\text { benda dan segala yang } \\
\text { dibendakan, dalam hal ini adalah } \\
\text { benda yaitu JPO. }\end{array}$ & $\begin{array}{l}\text { Kekurangan memiliki arti dalam kelas } \\
\text { verba atau kata kerja sehingga } \\
\text { kekurangan dapat menyatakan suatu } \\
\text { tindakan, } \\
\text { pengalaman, atau peberadaan, } \\
\text { dinamis pengertian } \\
\text { dan nomina atau kata benda. }\end{array}$ & $\begin{array}{l}\text { Skala } \\
\text { Likert }\end{array}$ \\
\hline $\begin{array}{l}\text { Alasan lebih } \\
\text { memilih melintas } \\
\text { di badan jalan } \\
(\mathrm{X} 9)\end{array}$ & $\begin{array}{l}\text { Merupakan suatu perasaan yang } \\
\text { timbul terhadap suatu kejadian } \\
\text { atau peristiwa dalam hal ini } \\
\text { dengan lebih memilih melintas di } \\
\text { badan jalan. }\end{array}$ & $\begin{array}{l}\text { Biasanya dipengaruhi oleh kondisi } \\
\text { dan keadaan sekitar seperti waktu, } \\
\text { jarak, kenyamanan dan faktor } \\
\text { lainnya. }\end{array}$ & $\begin{array}{l}\text { Skala } \\
\text { Likert }\end{array}$ \\
\hline $\begin{array}{l}\text { Penilaian } \\
\text { Keselamatan } \\
(\mathrm{X} 10.1)\end{array}$ & $\begin{array}{l}\text { Penilaian keselamatan yaitu } \\
\text { suatu bentuk yang dinyatakan } \\
\text { dalam angka atas perasaan } \\
\text { seseorang terhadap suatu objek } \\
\text { dalam hal ini adalah JPO. }\end{array}$ & $\begin{array}{l}\text { Dimana pengguna merasa dalam } \\
\text { keadaan aman, dalam suatu kondisi } \\
\text { yang aman secara fisik, spiritual, } \\
\text { emosional, psikologis. }\end{array}$ & $\begin{array}{l}\text { Skala } \\
\text { Likert }\end{array}$ \\
\hline
\end{tabular}




\begin{tabular}{|c|c|c|c|}
\hline $\begin{array}{l}\text { Penilaian } \\
\text { Keamanan } \\
(\mathrm{X} 10.2)\end{array}$ & $\begin{array}{l}\text { Penilaian keamanan yaitu suatu } \\
\text { bentuk yang dinyatakan dalam } \\
\text { angka atas perasaan seseorang } \\
\text { terhadap suatu objek dalam hal } \\
\text { ini adalah JPO. }\end{array}$ & $\begin{array}{l}\text { Dimana pengguna merasa dalam } \\
\text { keadaan aman, dalam suatu kondisi } \\
\text { yang aman secara fisik, spiritual, } \\
\text { emosional, psikologis. }\end{array}$ & $\begin{array}{l}\text { Skala } \\
\text { Likert }\end{array}$ \\
\hline $\begin{array}{l}\text { Penilaian } \\
\text { Kenyamanan } \\
(\mathrm{X} 10.3)\end{array}$ & $\begin{array}{l}\text { Penilaian kenyamanan yaitu } \\
\text { suatu bentuk yang dinyatakan } \\
\text { dalam angka atas perasaan } \\
\text { seseorang terhadap suatu objek } \\
\text { dalam hal ini adalah JPO. }\end{array}$ & $\begin{array}{l}\text { Dimana pengguna merasa bahwa } \\
\text { JPO memberikan kenyamanan baik } \\
\text { dari segi fisik, spiritual, emosional, } \\
\text { psikologis. }\end{array}$ & $\begin{array}{l}\text { Skala } \\
\text { Likert }\end{array}$ \\
\hline $\begin{array}{l}\text { Penilaian } \\
\text { Keindahan } \\
(X 10.4)\end{array}$ & $\begin{array}{l}\text { Penilaian keindahan yaitu suatu } \\
\text { bentuk yang dinyatakan dalam } \\
\text { angka atas perasaan seseorang } \\
\text { terhadap suatu objek dalam hal } \\
\text { ini adalah JPO. }\end{array}$ & $\begin{array}{l}\text { Dimana pengguna merasa bahwa } \\
\text { JPO memberikan senang dan } \\
\text { nyaman baik dari segi fisik, maupun } \\
\text { kondisi di sekeliling JPO terhadap } \\
\text { dirinya. }\end{array}$ & $\begin{array}{l}\text { Skala } \\
\text { Likert }\end{array}$ \\
\hline $\begin{array}{l}\text { Responden } \\
\text { (Y) }\end{array}$ & $\begin{array}{l}\text { Responden merupakan } \\
\text { narasumber yang dimintai data } \\
\text { dengan cara wawancara }\end{array}$ & $\begin{array}{l}\text { Faktor yang akan } \\
\text { mempengaruhi data yaitu dari segi } \\
\text { umur, jenis kelamin, dan jenis } \\
\text { pekerjan }\end{array}$ & $\begin{array}{l}\text { Skala } \\
\text { Likert }\end{array}$ \\
\hline
\end{tabular}

\section{Pengumpulan Data}

Pengumpulan data dilakukan dengan cara wawancara (interview) langsung (bertatap muka) menggunakan kuisioner untuk mendapatkan datadata yang dibutuhkan agar mendapatkan karakteristik dan persepsi daripada pejalan kaki akan disajikan secara deskriptif. Pada tahap ini dilakukan wawancara kepada pejalan kaki pada Jembatan Penyeberangan Orang di depan Toko Ramayana Jalan A.P. Pettarani yang telah dipilih sebagai tempat pelaksanaan survey.

\section{Data Primer}

Data primer merupakan data yang diperoleh dari peninjauan langsung di lapangan. Dimana data primer tersebut diperoleh dengan melakukan survey berupa kuisioner kepada para pejalan kaki yang berada di sekitaran jembatan penyeberangan khususnya dari jembatan penyeberangan ke depan Kantor Bina Marga dan Bhineka Life, setelah itu dilakukan wawancara berdasarkan instrument kuisioner sebanyak 10 pertanyaan dimana di dalamnya terdapat variabel karakteristik pejalan kaki dan dan persepsi pejalan kaki.

Pengambilan sampel dilakukan dengan cara Random Sampling yaitu pengambilan sampel tanpa memperhatikan strata atau tingkatan di dalam populasi. Wawancara sendiri menggunakan instrumen kuisioner dimana responden dipilih secara acak saat pejalan kaki berada di area pengambilan sampel atau area penelitian. Data dari tiap-tiap kuisioner kemudian mengelompokkan angket isian berdasarkan pedoman wawancara responden, dengan memberikan kode tertentu seperti tanda checklist pada setiap instrument kuesioner.

\section{Data Sekunder}

Data sekunder yaitu data yang diperoleh dari instansi-instansi terkait dan karya tulis terkait dengan penelitian ini. Literatur yang berkaitan serta jumlah penduduk yang berada di daerah A.P. Pettarani untuk mengetahui populasi serta jumlah sampel yang dibutuhkan. Data populasi sendiri merupakan jumlah penduduk yang berada area penelitian di A.P. Pettarani, sedangkan rumus sampel yaitu jumlah $10 \%$ dari populasi yang ada sehingga dapat mewakili data yang lain. Jumlah populasi adalah penduduk yang di berada di lokasi penelitian sesuai dengan data sensus penduduk di kecamatan terdekat 143.783 jiwa (Rumus Slovin).

Diketahui : $\mathrm{N}=143.783$ jiwa

$\mathrm{e}=$ batas toleransi kesalahan $10 \%$ (error tolerance) maka; $\mathrm{n}=\mathrm{N} /(1+\mathrm{Ne} 2)$

$=\quad 143.783$

$(1+143.783 \times 0,12)=99,93 \approx 100$ sampel

Jadi, jumlah sampel yang dibutuhkan untuk mewakili jumlah populasi yang ada yaitu sebesar 100 sampel.

Data diolah dengan menggunakan aplikasi SPSS 24 for Windows kemudian direkapitulasi menggunakan Program Excel dan dimasukkan ke dalam bentuk tabel dan grafik. 


\section{Teknik Analisis Data}

\section{Kelengkapan Data}

Tahap ini dilakukan segera setelah data terkumpul. Peneliti bisa membuat ceklist untuk memastikan apakah semua data sudah terkumpul. Penting untuk melakukan justifikasi bahwa data yang terkumpul sudah layak untuk dianalisis. Justifikasi tersebut tentu didasarkan pada desain riset awal tentang data apa saja yang dibutuhkan untuk menjawab pertanyaan penelitian. Singkatnya, jika data dirasa cukup, maka bisa dianggap sudah lengkap.

\section{Kualitas Data}

Terlebih dahulu mengkualitatifkan skor setiap hasil pilihan responden. Supaya memudahkan dalam menganalisis data, perlu diketahui skor yang diperoleh responden dari hasil pengisian kuesioner yang diberikan. Oleh karena itu ditentukan penetapan hasil skornya.

Tabel 2. Karakteristik responden

\begin{tabular}{|c|c|c|}
\hline Kode & Variabel & Skor \\
\hline $\mathrm{jk}$ & jenis kelamin & $\begin{array}{l}P= \\
\text { Perempua } \\
n L=\text { Laki- } \\
\text { laki }\end{array}$ \\
\hline umur & usia responden & $\begin{array}{l}1=\text { lebih dari } 46 \text { tahun } \\
2=37-46 \text { tahun } \\
3=27-36 \text { tahun } \\
4=17-26 \text { tahun } \\
5=\text { kurang dari } 17 \text { tahun }\end{array}$ \\
\hline pekerjaan & jenis pekerjaan & $\begin{array}{l}1=\text { BUMN } \\
2=\text { pelajar/Mahasiswa } 3 \\
=\text { Pegawai Swasta } \\
4=\text { Wiraswasta } \\
5=\text { Pegawai Negeri } \\
6=\text { Lainnya }\end{array}$ \\
\hline
\end{tabular}

Tabel 3 Pembagian Skoring

\begin{tabular}{|c|c|c|}
\hline No. & Variabel & Skor \\
\hline 1 & Persepsi & $\begin{array}{l}1=\text { Lainnya } \\
2=\text { Berbelanja } \\
3=\text { Rekreasi } \\
4=\text { Sekolah } / \text { Kuliah } \\
5=\text { Bekerja }\end{array}$ \\
\hline 2 & Persepsi & $\begin{array}{l}1=\text { Tidak sama sekali } \\
2=1-2 \text { kali seminggu } \\
3=3-4 \text { kali seminggu } \\
4=5-6 \text { kali seminggu } \\
5=\text { Lebih dari } 6 \text { kali }\end{array}$ \\
\hline 3 & Persepsi & $\begin{array}{l}1 \text { = Sangat jauh } \\
2=\text { Jauh } \\
3=\text { Dekat } \\
4=\text { Lumayan dekat } \\
5=\text { Sangat dekat }\end{array}$ \\
\hline 4 & Persepsi & $\begin{array}{l}1=\text { Sangat tidak baik } \\
2=\text { Tidak baik } \\
3=\text { Cukup baik } \\
4=\text { Baik } \\
5=\text { Sangat baik }\end{array}$ \\
\hline 5 & Persepsi & $\begin{array}{l}1=\text { Sangat tidak nyaman } \\
2=\text { Tidak nyaman } \\
3=\text { Cukup nyaman } \\
4=\text { Nyaman } \\
5=\text { Sangat nyaman }\end{array}$ \\
\hline
\end{tabular}




\begin{tabular}{|c|c|c|}
\hline 6 & Persepsi & $\begin{array}{l}1=\text { Malas menggunakan } \\
2=\text { Tidak terbiasa } \\
3=\text { Tidak nyaman } \\
4=\text { Kotor } \\
5=\text { Jauh }\end{array}$ \\
\hline 7 & Persepsi & $\begin{array}{l}1=\text { Tidak ada } \\
2=\text { Lebih ada rasa tanggungjawab terhadap kelancaran lalulintas } \\
3=\text { Lebih ada rasa tanggungjawab untuk menggunakan fasilitas } \\
\text { yang tersedia } \\
4=\text { Cepat tiba di tempat tujuan } \\
5=\text { Rasa aman }\end{array}$ \\
\hline 8 & Persepsi & $\begin{array}{l}1=\text { Kurang bermanfaat } \\
2=\text { Tangganya terlalu tinggi } \\
3=\text { Kurang terawatt } \\
4=\text { Kotor } \\
5=\text { Bersih }\end{array}$ \\
\hline 9 & Persepsi & $\begin{array}{l}1=\text { Lainnya } \\
2=\text { Lebih mudah } \\
3=\text { Lebih cepat } \\
4=\text { Lebih nyaman } \\
5=\text { Lebih leluasa }\end{array}$ \\
\hline 10 & Penilaian & $\begin{array}{l}1=\text { Sangat tidak baik } \\
2=\text { Tidak baik } \\
3=\text { Biasa } \\
4=\text { Baik } \\
5=\text { Sangat Baik }\end{array}$ \\
\hline
\end{tabular}

\section{HASIL DAN PEMBAHASAN}

\section{Karakteristik Responden}

\section{Jenis Kelamin}

Tabel 4.Karakteristik responden berdasarkan jenis kelamin

\begin{tabular}{|c|c|c|c|}
\hline \multirow{2}{*}{ Jenis Kelamin } & \multicolumn{3}{|c|}{ Waktu } \\
\cline { 2 - 4 } & $\begin{array}{c}\text { Hari ke- } \\
1 \%)\end{array}$ & $\begin{array}{c}\text { Hari ke-2 } \\
(\%)\end{array}$ & $\begin{array}{c}\text { Hari ke-3 } \\
(\%)\end{array}$ \\
\hline Laki-laki & 41.94 & 62.79 & 50 \\
\hline Perempuan & 58.06 & 37.21 & 50 \\
\hline Total (\%) & 100.00 & 100.00 & 100.00 \\
\hline
\end{tabular}

Persentase terbesar pejalan kaki berdasarkan jenis kelamin yaitu pada hari kedua didominasi oleh Lakilaki dengan persentase sebesar $62,79 \%$ dan Perempuan sebesar $37,21 \%$ dari 43 orang. Kemudian pada hari pertama didominasi oleh Perempuan dengan persentase sebesar $58,09 \%$ dan Laki- laki sebesar $41,94 \%$ dari 31 orang. Selanjutnya pada hari ketiga didominasi oleh keduanya atau dalam artian keduanya berada pada persentase yang sama yaitu $50 \%$ dari 26 orang.

\section{Umur}

Persentase responden terbesar berdasarkan umur yaitu pada hari kedua, umur $<17$ tahun sebesar 13,95 $\%$, umur $17-26$ tahun sebesar $30,23 \%$, umur $27-36$ tahun sebesar $34,88 \%$, umur 37-46 tahun sebesar $16,28 \%$, dan umur $>46$ tahun sebesar $4,65 \%$ yang mewakili 43 orang responden. Sedangkan pada hari pertama, umur $<17$ tahun sebesar $6,45 \%$, umur 17 26 tahun sebesar 70,97 \%, umur 37-46 tahun sebesar $16,13 \%$, dan umur $>46$ tahun sebesar 6,45 $\%$ yang mewakili 31 orang responden. Kemudian pada hari ketiga, umur $<17$ tahun sebesar $3,85 \%$, umur 17-26 tahun sebesar 73,08 \%, umur 27-36 tahun sebesar 11,54 \%, dan umur 37-46 tahun sebesar $11,54 \%$ yang mewakili 26 orang responden.

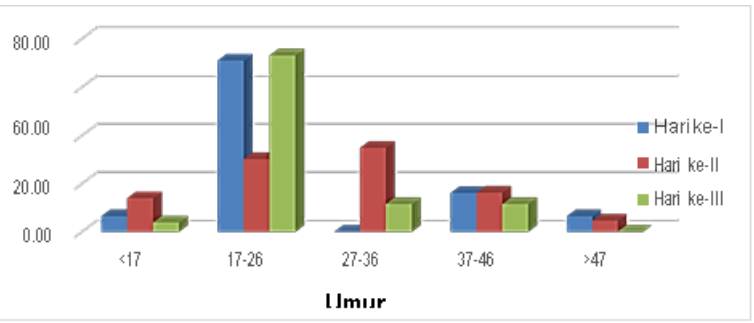

Gambar 2. Karakteristik responden berdasarkan umur

Pekerjaan 


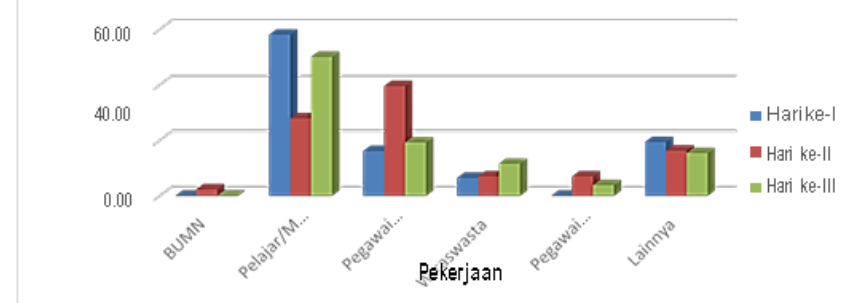

Gambar 3. Karakteristik responden berdasarkan pekerjaan

Persentase responden terbesar berdasarkan jenis pekerjaan yaitu pada hari kedua yang didominasi oleh BUMN sebesar 2,33 \%, Pelajar/Mahasiswa sebesar 27,91\%, Pegawai Swasta sebesar 39,53\%, Wiraswasta sebesar 6,98\%, Pegawai Negeri sebesar 6,98 \%, dan Lainnya sebesar 16,28 \% yang mewakili 43 orang responden. Sedangkan pada hari pertama didominasi oleh Pelajar/Mahasiswa sebesar $58,06 \%$, Pegawai Swasta sebesar 16,13\%, Wiraswasta sebesar 6,45 \%, dan Lainnya sebesar $19,35 \%$ yang mewakili 31 orang responden. Kemudian pada hari ketiga didominasi oleh Pelajar/Mahasiswa sebesar 50,00 \%, Pegawai Swasta sebesar 19,23\%, Wiraswasta sebesar 11,54 $\%$, Pegawai Negeri sebesar 3,85 \%, dan Lainnya sebesar 15,38\% yang mewakili 26 orang responden.

\section{Persepsi Pejalan Kaki}

\section{Tujuan Perjalanan}

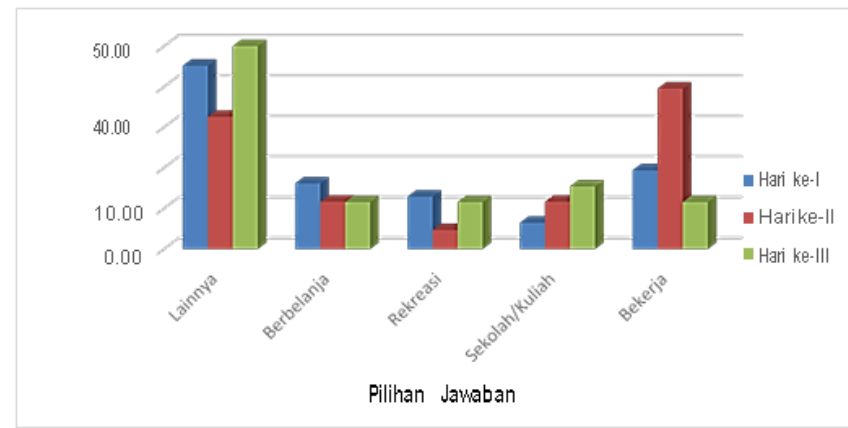

Gambar 4. Persepsi pejalan kaki berdasarkan tujuan perjalanan

Persentase jawaban responden terbesar berdasarkan tujuan perjalanan yaitu pada hari kedua yang didominasi oleh pilihan jawaban, Lainnya sebesar 32,56\%, Berbelanja sebesar 11,63\%, Rekreasi 4,65\%, Sekolah/Kuliah sebesar 11,63\%, dan Bekerja sebesar 39,53\% dari 43 orang. Kemudian pada hari pertama yang didominasi oleh pilihan jawaban, Lainnya sebesar 45,16\%, Berbelanja sebesar 16,13\%, Rekreasi 12,90

$\%$, Sekolah/Kuliah sebesar 6,45 \%, dan Bekerja sebesar 19,35\% dari 31 orang. Selanjutnya pada hari ketiga yang didominasi oleh pilihan jawaban, Lainnya sebesar 50,00\%, Berbelanja sebesar 11,54\%,
Rekreasi 11,54\%, Sekolah/Kuliah sebesar 15,38\%, dan Bekerja sebesar 11,54 \% dari 26 orang.

\section{Frekuensi Menggunakan Jembatan Penyeberangan Orang}

Persentase jawaban responden terbesar berdasarkan frekuensi menggunakan Jembatang Penyeberangan Orang yaitu pada hari kedua yang didominasi oleh pilihan jawaban, Tidak sama sekali sebesar 13,95 \%, 1-2 kali seminggu sebesar 16,28 $\%$, 3-4 kali seminggu sebesar 2,98 \%, 5-6 kali seminggu sebesar $6,98 \%$, dan $>6$ kali sebesar 20,93 $\%$ dari 43 orang. Kemudian pada hari pertama yang didominasi oleh pilihan jawaban, Tidak sama sekali sebesar 32,26\%, 1-2 kali seminggu sebesar 35,48 $\%$, 3-4 kali seminggu sebesar 6,45 \%, 5-6 kali seminggu sebesar $12,90 \%$, dan $>6$ kali sebesar $12,90 \%$ dari 31 orang. Selanjutnya pada hari ketiga yang didominasi oleh pilihan jawaban, Tidak sama sekali sebesar 7,69 \%, 1-2 kali seminggu sebesar $42,31 \%$, 3-4 kali seminggu sebesar 19,23\%, 5-6 kali seminggu sebesar $3,85 \%$, dan $>6$ kali sebesar 26,92 $\%$ dari 26 orang.

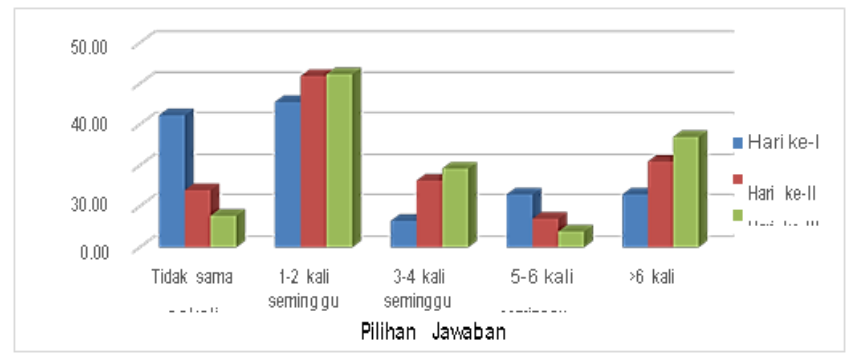

Gambar 5. Persepsi pejalan kaki terhadap frekuensi menggunakan jembatan penyeberangan orang

Jarak Tempuh

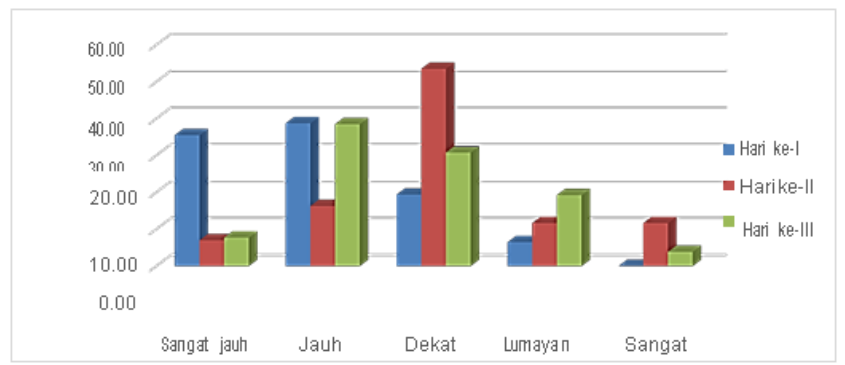

Gambar 6. Persepsi pejalan kaki berdasarkan jarak tempuh

Persentase jawaban responden terbesar berdasarkan jarak tempuh yaitu pada hari kedua yang didominasi oleh pilihan jawaban, Sangat jauh sebesar 6,98 \%, Jauh sebesar 16,28 \%, Dekat sebesar 53,49\%, Lumayan dekat sebesar 11,63\%, dan Sangat dekat sebesar $11,63 \%$ dari 43 orang. Kemudian pada hari pertama yang didominasi oleh pilihan jawaban, Sangat jauh sebesar 35,48 \%, Jauh sebesar 38,71 \%, Dekat sebesar 19,35\%, dan 
Lumayan dekat sebesar $6,45 \%$ dari 31 orang. Selanjutnya pada hari ketiga yang didominasi oleh pilihan jawaban, Sangat jauh sebesar 7,69 \%.

\section{Kondisi Jembatan Penyeberangan Orang}

Persentase jawaban responden terbesar berdasarkan kondisi fasilitas yaitu pada hari kedua yang didominasi oleh pilihan jawaban, Sangat tidak baik sebesar 2,33 \%, Tidak baik sebesar $11,63 \%$, Cukup baik sebesar $37,21 \%$, Baik sebesar $37,21 \%$, dan Sangat baik sebesar $11,63 \%$ dari 43 orang. Kemudian pada hari pertama yang didominasi oleh pilihan jawaban, Sangat tidak baik sebesar 3,23 \%, Tidak baik sebesar $6,45 \%$, Cukup baik sebesar $51,61 \%$, Baik sebesar $25,81 \%$, dan Sangat baik sebesar $12,90 \%$ dari 31 orang. Selanjutnya pada hari ketiga yang didominasi oleh pilihan jawaban, Tidak baik sebesar 26,92 \%, Cukup baik sebesar 38,46\%, dan Baik sebesar 34,62 \% dari 26 orang.

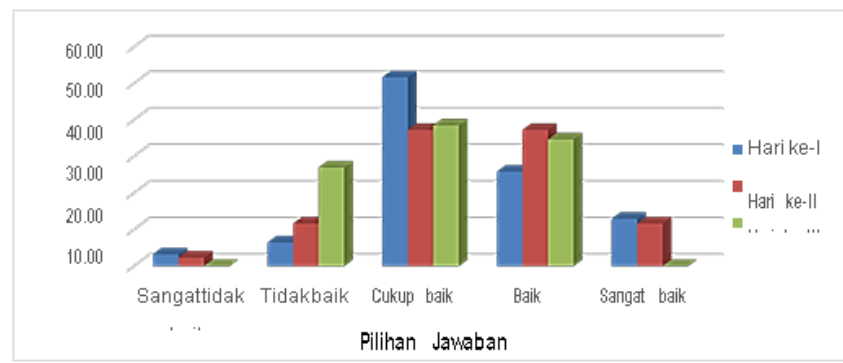

Gambar 7. Persepsi pejalan kaki terhadap kondisi jembatan penyeberangan orang

\section{Kenyamanan}

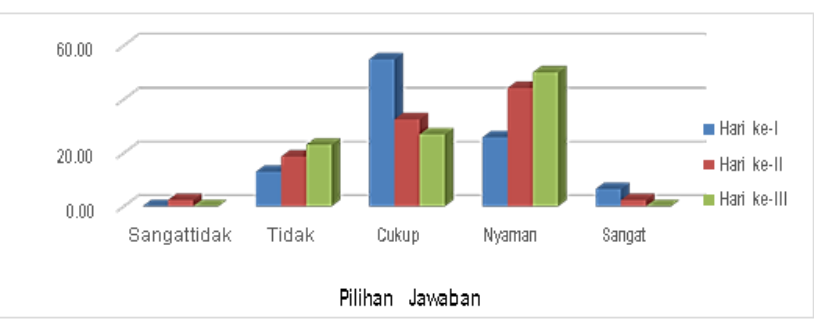

Gambar 8. Persepsi pejalan kaki terhadap kenyamanan

Persentase jawaban responden terbesar berdasarkan kenyamanan yaitu pada hari kedua yang didominasi oleh pilihan jawaban, Sangat tidak nyaman sebesar 2,33\%, Tidak nyaman sebesar $18,60 \%$, Cukup nyaman sebesar 32,56 \%, Nyaman sebesar 44,19\%, dan Sangat nyaman sebesar 2,33 $\%$ dari 43 orang. Kemudian pada hari pertama yang didominasi oleh pilihan jawaban, Tidak nyaman sebesar $12,90 \%$, Cukup nyaman sebesar $54,84 \%$, Nyaman sebesar $25,81 \%$, dan Sangat nyaman sebesar $6,45 \%$ dari 31 orang. Selanjutnya pada hari ketiga yang didominasi oleh pilihan jawaban, Tidak nyaman sebesar $23,08 \%$, Cukup nyaman sebesar
26,92 \%, dan Nyaman sebesar 50,00 \% dari 26 orang.

Faktor penyebab tidak menggunakan jembatan penyeberangan orang

Persentase jawaban responden terbesar berdasarkan alasan tidak menggunakan fasilitas Jembatan Penyeberangan Orang yaitu pada hari kedua yang didominasi oleh pilihan jawaban, Malas menggunakan sebesar $46,51 \%$, Tidak terbiasa sebesar 23,26 \%, Tidak nyaman sebesar $6,98 \%$, Kotor sebesar $13,95 \%$, dan Jauh sebesar 9,30\% dari 43 orang. Kemudian pada hari pertama yang didominasi oleh pilihan jawaban, Malas menggunakan sebesar 22,58 \%, Tidak terbiasa sebesar 19,35 \%, Tidak nyaman sebesar $19,35 \%$, Kotor sebesar $16,13 \%$, dan Jauh sebesar 22,58 \% dari 31 orang. Selanjutnya pada hari ketiga yang didominasi oleh pilihan jawaban, Malas menggunakan sebesar 34,62 \%, Tidak terbiasa sebesar $11,54 \%$, Tidak nyaman sebesar $615,38 \%$, Kotor sebesar 30,77 \%, dan Jauh sebesar 7,69 \% dari 26 orang. Jauh sebesar 38,46\%, Dekat sebesar $30,77 \%$, Relatif dekat sebesar $19,23 \%$, dan Sangat dekat sebesar $3,85 \%$ dari 26 orang.

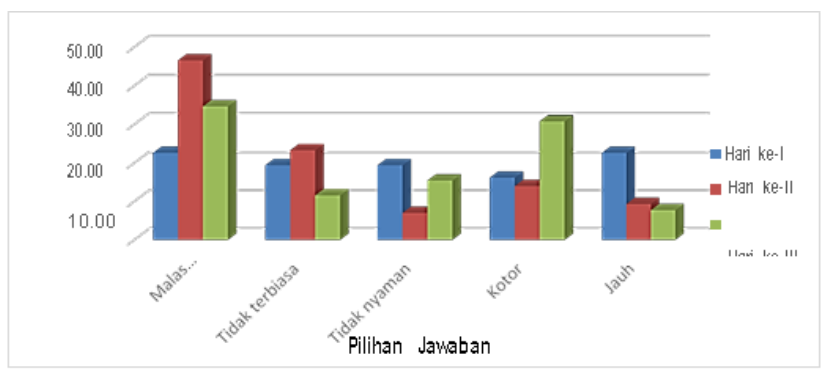

Gambar 9. Penyebab pejalan kaki tidak menggunakan jembatan penyeberangan orang

Alasan menggunakan jembatan penyeberangan orang

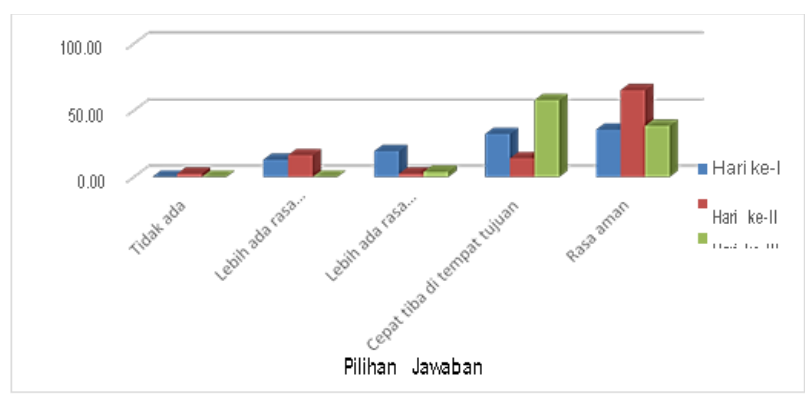

Gambar 10. Faktor penyebab pejalan kaki menggunakan jembatan penyeberangan orang

Persentase jawaban responden terbesar berdasarkan alasan menggunakan fasilitas Jembatan Penyeberangan Orang yaitu pada hari kedua yang didominasi oleh pilihan jawaban, Tidak ada sebesar 2,33 \%, Lebih ada rasa tanggungjawab 
terhadap lalu lintas sebesar $16,28 \%$, Lebih ada rasa tanggungjawab untuk menggunakan fasilitas yang tersedia sebesar $2,33 \%$, Cepat tiba di tempat tujuan sebesar 13,95\%, dan Rasa aman sebesar 65,12\% dari 43 orang. Kemudian pada hari pertama yang didominasi oleh pilihan jawaban, Lebih ada rasa tanggungjawab terhadap lalu lintas sebesar $12,90 \%$, Lebih ada rasa tanggungjawab untuk menggunakan fasilitas yang tersedia sebesar $19,35 \%$, Cepat tiba di tempat tujuan sebesar 32,26\%, dan Rasa aman sebesar $35,48 \%$ dari 31 orang. Selanjutnya pada hari ketiga yang didominasi oleh pilihan jawaban, Lebih ada rasa tanggungjawab untuk menggunakan fasilitas yang tersedia sebesar $3,85 \%$, Cepat tiba di tempat tujuan sebesar $57,69 \%$, dan Rasa aman sebesar $38,46 \%$ dari 26 orang.

Kekurangan dari fasilitas jembatan penyeberangan orang

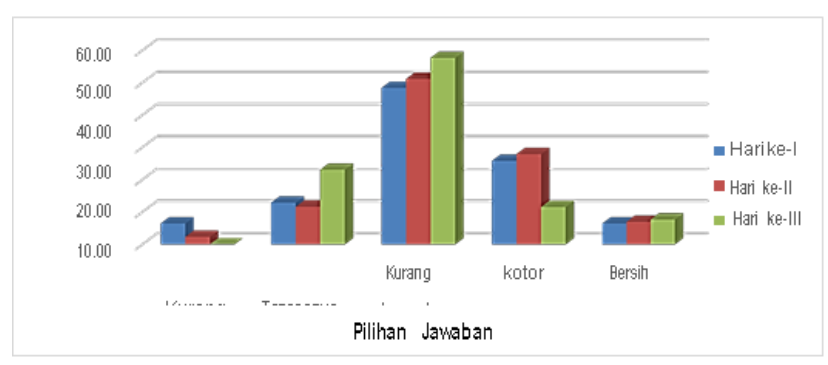

Gambar 11. Kekurangan dari fasilitas jembatan penyeberangan orang

Persentase jawaban responden terbesar berdasarkan kekurangan fasilitas Jembatan Penyeberangan Orang yaitu pada hari kedua yang didominasi oleh pilihan jawaban, Kurang bermanfaat sebesar 2,33\%, Tangganya terlali tinggi sebesar $11,63 \%$, Kurang terawat sebesar $51,16 \%$, Kotor sebesar 27,91\%, dan Bersih sebesar 6,98 \% dari 43 orang. Kemudian pada hari pertama yang didominasi oleh pilihan jawaban, Kurang bermanfaat sebesar $6,45 \%$, Tangganya terlali tinggi sebesar $12,90 \%$, Kurang terawat sebesar $48,39 \%$, Kotor sebesar $25,81 \%$, dan Bersih sebesar $6,45 \%$ dari 31 orang. Selanjutnya pada hari ketiga yang didominasi oleh pilihan jawaban, Tangganya terlali tinggi sebesar $23,08 \%$, Kurang terawat sebesar 57,69 \%, Kotor sebesar 11,54\%, dan Bersih sebesar 7,69 \% dari 26 orang.

\section{Alasan memilih melintas di badan jalan}

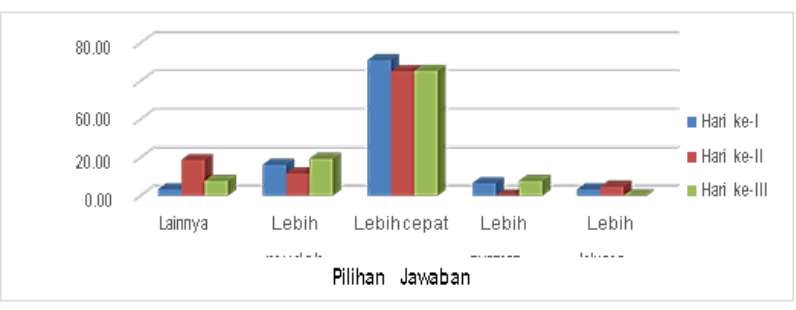

Gambar 12. Alasan memilih melintas di badan jalan

Persentase jawaban responden terbesar berdasarkan alasan lebih memilih melintas di badan jalan yaitu pada hari kedua yang didominasi oleh pilihan jawaban, Lainnya sebesar $18,60 \%$, Lebih mudah sebesar $11,63 \%$, Lebih cepat sebesar 65,12 $\%$, dan Bersih sebesar 4,65 \% dari 43 orang. Kemudian pada hari pertama yang didominasi oleh pilihan jawaban, Lainnya sebesar 3,23\%, Lebih mudah sebesar $16,13 \%$, Lebih cepat sebesar 70,97 $\%$, Lebih nyaman sebesar 6,45 \%, dan Bersih sebesar 3,23 \% dari 31 orang. Selanjutnya pada hari ketiga yang didominasi oleh pilihan jawaban, Lainnya sebesar 7,69 \%, Lebih mudah sebesar 19,23\%, Lebih cepat sebesar $65,38 \%$, dan Lebih nyaman sebesar 7,69\% dari 26 orang.

\section{Keselamatan dari jembatan penyeberangan orang}

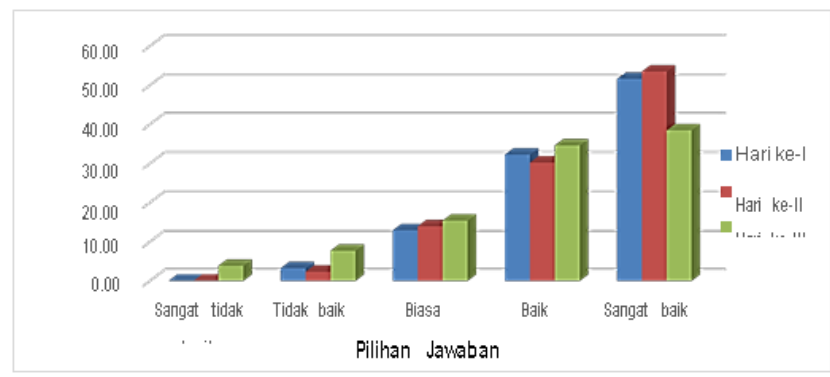

Gambar 13. Keselamatan dari jembatan penyeberangan orang

Persentase jawaban responden terbesar berdasarkan penilaian Jembatan Penyeberangan Orang A.P. Pettarani yaitu pada hari kedua yang didominasi oleh pilihan jawaban, Tidak baik sebesar $2,33 \%$, Biasa sebesar 13,95 \%, Baik sebesar 30,23 $\%$, Sangat baik sebesar $53,49 \%$ dari 43 orang. Kemudian pada hari pertama yang didominasi oleh pilihan jawaban, Tidak baik sebesar 3,23\%, Biasa sebesar $12,90 \%$, Baik sebesar 32,26\%, Sangat baik sebesar $51,61 \%$ dari 31 orang. Selanjutnya pada hari ketiga yang didominasi oleh pilihan jawaban, Sangat tidak baik sebesar 3,58 \%, Tidak baik sebesar 7,69 $\%$, Biasa sebesar $15,38 \%$, Baik sebesar $34,62 \%$, Sangat baik sebesar $38,46 \%$ dari 26 orang.

\section{Regresi Linier}


Tabel 5. Variabel yang dimasukkan/dihilangkan

\begin{tabular}{|l|l|l|l|}
\hline \multicolumn{4}{|c|}{ Variables Entered/Removed $^{\mathbf{a}}$} \\
\hline \multirow{3}{*}{ Model } & $\begin{array}{l}\text { Variables } \\
\text { Variables } \\
\text { Entered }\end{array}$ & Removed & Method \\
\hline
\end{tabular}

\begin{tabular}{|l|l|l|}
\hline 1 & $\begin{array}{l}\text { X10.4, X4, X9, } \\
\text { X2, X6, X10.2, } \\
\text { X1, X7, X8, X3, } \\
\text { X10.3, } \\
\text { X5, } \\
\text { X10.1 } \mathrm{b}\end{array}$ & \\
\hline a. Dependent Variable: Responden & \\
\hline b. All requested variables entered. & \\
\hline
\end{tabular}

Tabel 6. Nilai F hitung

\begin{tabular}{|c|c|c|c|c|c|}
\hline \multicolumn{6}{|c|}{ ANOVA $^{a}$} \\
\hline Model & Sum of Squares & df & Mean Square & $\mathrm{F}$ & Sig. \\
\hline 1 Regression & 18752.892 & 13 & 1442.530 & 1.921 & $.038^{b}$ \\
\hline Residual & 64572.108 & 86 & 750.838 & & \\
\hline Total & 83325.000 & 99 & & & \\
\hline \multicolumn{6}{|c|}{ a. Dependent Variable: Responden } \\
\hline b. Predictors: & ant), $\mathrm{X} 10.4, \mathrm{X}$ & $x 9, x$ & $10.2, X 1, X 7$ & $\mathrm{x} 3, \mathrm{X} 10$. & 10.1 \\
\hline
\end{tabular}

\section{Dasar Pengambilan Keputusan (Uji F)}

Jika nilai sig $<0,05$, atau $F$ hitung $>F$ tabel maka terdapat pengaruh variabel $\mathrm{X}$ terhadap $\mathrm{Y}$.

Jika nilai sig $>0,05$, atau $F$ hitung $<\mathrm{F}$ tabel maka tidak terdapat pengaruh variabel $\mathrm{X}$ terhadap $\mathrm{Y}$.

Jika; $\mathrm{k}=$ Jumlah variabel $\mathrm{X} \mathrm{n}=$ Jumlah sampel

Maka; Ftabel $=F(13 ; 100-13)=F(13 ; 87)$

Dari tabel didapat Ftabel $=1,83$

Berdasarkan hasil SPSS dengan nilai sig $=0,038<\alpha$ $=0,05$ (Diterima)

Fhitung $=1,921>$ Ftabel $=1,831$

(Diterima)

Sehingga dapat disimpulkan berdasarkan Uji nilai $F$ bahwa $F$ diterima berarti terdapat pengaruh simultan (bersama-sama) yang diberikan variabel $\mathrm{X}$ terhadap variabel $\mathrm{Y}$.

Dasar Pengambilan Keputusan (Uji t)

Jika nilai sig $<0,05$, atau $\mathrm{t}$ hitung $>\mathrm{t}$ tabel maka terdapat pengaruh variabel $X$ terhadap $Y$.

Jika nilai sig $>0,05$, atau $t$ hitung $<\mathrm{t}$ tabel maka tidak terdapat pengaruh variabel $\mathrm{X}$ terhadap $\mathrm{Y}$.
Jika; $\alpha=$ Tingkat kesalahan $(5 \%=0,05) \mathrm{k}=$ Jumlah variabel $X$

$\mathrm{n}=$ Jumlah sampel

Maka; ttabel $=\mathrm{t}(0,05 / 2 ; 100-13-1)$

$=\mathrm{t}(0,025 ; 86)$

Dari tabel didapat ttabel $=1,991$ Berdasarkan hasil SPSS

$\mathrm{X} 1$ dengan nilai $\operatorname{sig}=0,570>\alpha=0,05 \quad$ (Ditolak) thitung $=-0,570<$ ttabel $=1,991$

(Ditolak)

Sehingga dapat disimpulkan berdasarkan Uji nilai $t$ bahwa $t$ ditolak berarti tidak terdapat pengaruh $X$ terhadap $\mathrm{Y}$.

$X 2$ dengan nilai sig $=0,186>\alpha=0,05 \quad$ (Ditolak) thitung $=1,333<$ ttabel $=1,991$ (Ditolak)

Sehingga dapat disimpulkan berdasarkan Uji nilai t bahwa $t$ ditolak berarti tidak terdapat pengaruh $X$ terhadap Y.

$\mathrm{X} 3$ dengan nilai sig $=0,012<\alpha=0,05 \quad$ (Diterima) thitung $=2,564>$ ttabel $=1,991$ (Diterima)

Sehingga dapat disimpulkan berdasarkan Uji nilai $t$ bahwa $t$ diterima berarti terdapat pengaruh $X$ terhadap Y. 
X4 dengan nilai sig $=0,114>\alpha=0,05 \quad$ (Ditolak) thitung $=-1,599<$ ttabel $=1,991$

(Ditolak)

Sehingga dapat disimpulkan berdasarkan Uji nilai $t$ bahwa $t$ ditolak berarti tidak terdapat pengaruh $X$ terhadap Y.

$X 5$ dengan nilai sig $=0,598>\alpha=0,05 \quad$ (Ditolak) thitung $=0,529<$ ttabel $=1,991$ (Ditolak)

Sehingga dapat disimpulkan berdasarkan Uji nilai $t$ bahwa $t$ ditolak berarti tidak terdapat pengaruh $X$ terhadap $Y$.

X6 dengan nilai sig $=0,514>\alpha=0,05$

(Ditolak)

thitung $=-0,656<$ ttabel $=1,991$

(Ditolak)

Sehingga dapat disimpulkan berdasarkan Uji nilai $t$ bahwa $t$ ditolak berarti tidak terdapat pengaruh $X$ terhadap $\mathrm{Y}$.

$\begin{array}{ll}X 7 \text { dengan nilai sig }=0,070>\alpha=0,05 & \text { (Ditolak) } \\ \text { thitung }=-1,838<\text { ttabel }=1,991 & \text { (Ditolak) }\end{array}$

Sehingga dapat disimpulkan berdasarkan Uji nilai $t$ bahwa $t$ ditolak berarti tidak terdapat pengaruh $X$ terhadap Y.

X8 dengan nilai sig $=0,182>\alpha=0,05 \quad$ (Ditolak)

thitung $=-1,346<$ ttabel $=1,991 \quad$ (Ditolak)

Sehingga dapat disimpulkan berdasarkan Uji nilai $t$ bahwa $t$ ditolak berarti tidak terdapat pengaruh $X$ terhadap Y.

X9 dengan nilai sig $=0,341>\alpha=0,05 \quad$ (Ditolak) thitung $=-0,978<$ ttabel $=1,991 \quad$ (Ditolak)

Sehingga dapat disimpulkan berdasarkan Uji nilai $t$ bahwa $t$ ditolak berarti tidak terdapat pengaruh $X$ terhadap Y.

X10.1 dengan nilai sig $=0,405>\alpha=0,05$ (Ditolak) thitung $=-0,837<$ ttabel $=1,991 \quad$ (Ditolak)

Sehingga dapat disimpulkan berdasarkan Uji nilai $t$ bahwa $t$ ditolak berarti tidak terdapat pengaruh $X$ terhadap Y.

$\mathrm{X} 10.2$ dengan nilai $\operatorname{sig}=0,610>a=0,05$ (Ditolak) thitung $=0,512<$ ttabel $=1,991$ (Ditolak)

Sehingga dapat disimpulkan berdasarkan Uji nilai $t$ bahwa $t$ ditolak berarti tidak terdapat pengaruh $X$ terhadap Y.

X10.3 dengan nilai sig $=0,693>\alpha=0,05$ (Ditolak)

thitung $=0,396<$ ttabel $=1,991$ (Ditolak)

Sehingga dapat disimpulkan berdasarkan Uji nilai $t$ bahwa $t$ ditolak berarti tidak terdapat pengaruh $X$ terhadap Y.
X10.4 dengan nilai sig $=0,874>\alpha=0,05$ (Ditolak) thitung $=-0,159<$ ttabel $=1,991 \quad$ (Ditolak)

Sehingga dapat disimpulkan berdasarkan Uji nilai $t$ bahwa $t$ ditolak berarti tidak terdapat pengaruh $X$ terhadap Y.

Dari tabel t hitung diketahui bahwa nilai c (constant) sebesar 53,532 dan juga melalui uji t yang diterima hanya X3 sebesar 7,693 , sehingga persamaan y menjadi $7,693 x+53,532$.

Tabel 7. Nilai $R^{2}$

\begin{tabular}{|l|c|c|c|c|}
\hline \multicolumn{5}{|c|}{\begin{tabular}{c} 
Model \\
Summary \\
\hline
\end{tabular}} \\
Model & $R$ & R Square & Adjusted & Std. Error of \\
& & & Squar & Estimate \\
& & & e & \\
\hline 1 & $.474^{\mathrm{a}}$ & .225 & .108 & 27.401 \\
\hline a. Predictors: (Constant), X10.4, X4, X9, X2, X6, X10.2, X1, X7, X8, X3, \\
X10.3, X5, X10.1
\end{tabular}

Berdasarkan output di atas diketahui nilai $\mathrm{R}$ Square sebesar 0,225, hal ini menunjukkan arti bahwa pengaruh variabel $X$ secara simultan (bersamasama) terhadap variabel $\mathrm{Y}$ adalah sebesar $22,5 \%$

\section{Pembahasan}

\section{Karakteristik Pejalan Kaki}

Berdasarkan hasil penelitian dengan menggunakan data penduduk dengan kecamatan terdekat sebagai jumlah sampel responden dan sudah mencakup penduduk dari kecamatan lainnya didapatkan bahwa, dari 31 responden pada hari pertama, diperoleh hasil untuk jenis kelamin yang didominasi oleh Perempuan dengan persentase sebesar 58,06 $\%$ untuk umur didominasi oleh umur 17-26 tahun dengan persentase sebesar $70,97 \%$, dan untuk jenis pekerjaan didominasi oleh Pelajar/Mahasiswa dengan persentase sebesar 58,06\%. Sedangkan 43 responden pada hari kedua, diperoleh hasil untuk jenis kelamin yang didominasi oleh Laki-laki dengan persentase sebesar $62,79 \%$, untuk umur didominasi oleh umur 27-36 tahun dengan persentase sebesar $34,88 \%$, dan untuk jenis pekerjaan didominasi oleh Pegawai Swasta dengan persentase sebesar 39,53 $\%$. Kemudian 26 responden pada hari ketiga, diperoleh hasil untuk jenis kelamin yang didominasi oleh Laki-laki dan Perempuan dengan persentase sebesar $50,00 \%$, untuk umur didominasi oleh umur 17-26 tahun dengan persentase sebesar $73,08 \%$, dan untuk jenis pekerjaan didominasi oleh 
Pelajar/Mahasiwa dengan persentase sebesar 50,00 $\%$.

\section{Persepsi Pejalan Kaki}

Berdasarkan hasil Regresi Linear menggunakan pengujian $F$ dan $t$ diketahui bahwa, variabel $X$ (persepsi) memiliki pengaruh secara simultan (bersama-sama) terhadap Y (Responden) tetapi dari semua persepsi yang diberikan hanya X3 (Jarak Tempuh) yang memiliki pengaruh terhadap $Y$ (Responden). Dengan R Square atau koefisien determinasi sebesar 0,225 , nilai ini berasal dari pengkuadratan nilai koefisien korelasi atau " $R$ " , yaitu $0,474 \times 0,474=0,225$. Besarnya angka koefisien determinasi ( $R$ Square) adalah 0,225 atau sama dengan $22,5 \%$ yang berarti variabel $\mathrm{X} 1$ (Tujuan Perjalanan), X2 (Frekuensi menggunakan Fasilitas Jembatan Penyeberangan Orang), X3 (Jarak Tempuh), X4 (Kondisi Fasilitas JPO), X5

(Kenyamanan), X6 (Alasan tidak menggunakan Fasilitas), X7(Alasan menggunakan Fasilitas), X8 (Kekurangan Failitas), X9 (Alasan Lebih Memilih Melintas di Badan Jalan), X10.1 (Penilaian tentang Keselamatan Jembatan Penyeberangan Orang A.P. Pettarani), X10.2 (Penilaian tentang Keamanan Jembatan Penyeberangan Orang A.P. Pettarani),

\section{DAFTAR PUSTAKA}

[1] L. Trianingsih dan R. Hidayah,2014, "Analisis Perilaku Pejalan Kaki Pada Penggunaan Fasilitas Penyeberangan di Sepanjang Jalan Kawasan Malioboro, Yogyakarta" INERSIA, Vol.10, no.2, doi: ttps://doi.org/10.21831/inersia.v10i2.9959

[2] L. N. Ikhsani dan P. Khadiyanta, 2015, "Persepsi Pengguna terhadap Jalur Pejalan Kaki Jalan Pemuda Kota Magelang," Media Plano, Vol.1, no.3, doi https://doi.org/10.14710/ruang.1.3.111-120
X10.3 (Penilaian tentang Kenyamanan Jembatan Penyeberangan Orang A.P. Pettarani), dan X10.4 (Penilaian tentang Keindahan Jembatan Penyeberangan Orang A.P. Pettarani) secara simultan (bersama-sama) berpengaruh terhadap variabel Y (Responden) sebesar 22,5\%. Sedangkan sisanya $(100 \%-22,5 \%=77,5 \%)$ dipengaruhi oleh variabel lain di luar persamaan regresi ini atau yang tidak diteliti.

\section{KESIMPULAN}

Karakteristik pejalan kaki berdasarkan jenis kelamin didominasi oleh laki-laki, berdasarkan umur didominasi oleh 17-26 tahun, berdasarkan jenis pekerjaan didominasi oleh Pelajar/Mahasiswa.

Persepsi pejalan kaki sangat bervariasi baik yang menggunakan maupun yang tidak menggunakan Jembatan Penyeberangan Orang A.P Pettarani. Dari semua variabel yang diteliti, variabel yang paling mempengaruhi adalah variabel $X 3$ yaitu jarak tempuh yang mana pada beberapa kasus dalam hal ini pejalan kaki enggan untuk menggunakan Jembatan Penyeberangan Orang karena jarak dari titik melakukan perjalanan ke tempat tujuan menjadi lebih jauh. Sehingga terkadang banyak pejalan kaki yang lebih memilih untuk melintas di badan jalan.

[3] A. Nadjam, M. Ferdiansyah, dan H. J. Sitorus, 2018. "Efektivitas dan Kepuasan Pengguna Jembatan Penyeberangan Orang di PAsar Induk Kramat Jati". J. Poli-Teknol., Vol. 17, no. 1, doi: 10.32722/pt.v17i1.1091.

[4] Muhlas H, dan Anak A, 2012, "Analisis Kebutuhan Fasilitas Penyeberangan Dan Perilaku Pejalan Kaki Menyeberang Di Ruas Jalan Kartini Bandar Lampung ", Jurnal Teknik ITS, Vol.1, doi: 10.12962/j23373539.v1i1.1233

[5] Z. A. Nur dan D. Suwandono, 2015, "Kajian Keamanan Jalur Pejalan Kaki Di Jalan Arteri Sekunder Berdasarkan Aspek Fisik Dan Masyarakat (Studi Kasus: Jalan Pemuda Kabupaten Klaten)," RUANG Vol. 1, no.1 